Prepared in cooperation with the New York State Department of Environmental Conservation
Q.
Changes in Low-Flow Frequency from 1976-2006 at Selected Sites in New York, Excluding Long Island

Scientific Investigations Report 2011-5112

U.S. Department of the Interior U.S. Geological Survey 
Cover. Schroon River, Riverbank, NY, looking downstream from bridge near U.S. Geological Survey streamgage. 


\section{Changes in Low-Flow Frequency from 1976-2006 at Selected Streamgages in New York, Excluding Long Island}

By Thomas P. Suro and Christopher L. Gazoorian

Prepared in cooperation with the

New York State Department of Environmental Conservation

Scientific Investigations Report 2011-5112

U.S. Department of the Interior

U.S. Geological Survey 


\section{U.S. Department of the Interior \\ KEN SALAZAR, Secretary \\ U.S. Geological Survey \\ Marcia K. McNutt, Director}

\section{U.S. Geological Survey, Reston, Virginia: 2011}

For product and ordering information:

World Wide Web: http://www.usgs.gov/pubprod

Telephone: 1-888-ASK-USGS

For more information on the USGS--the Federal source for science about the Earth, its natural and living resources, natural hazards, and the environment:

World Wide Web: http://www.usgs.gov

Telephone: 1-888-ASK-USGS

Any use of trade, product, or firm names is for descriptive purposes only and does not imply endorsement by the U.S. Government.

Although this report is in the public domain, permission must be secured from the individual copyright owners to reproduce any copyrighted materials contained within this report.

Suggested citation:

Suro, T.P., and Gazoorian, C.L., 2011, Changes in low-flow frequency from 1976-2006 at selected streamgages in New York, excluding Long Island: U.S. Geological Survey Scientific Investigations Report 2011-5112, 21 p., at http://pubs.usgs.gov/sir/2011/5112. 


\section{Contents}

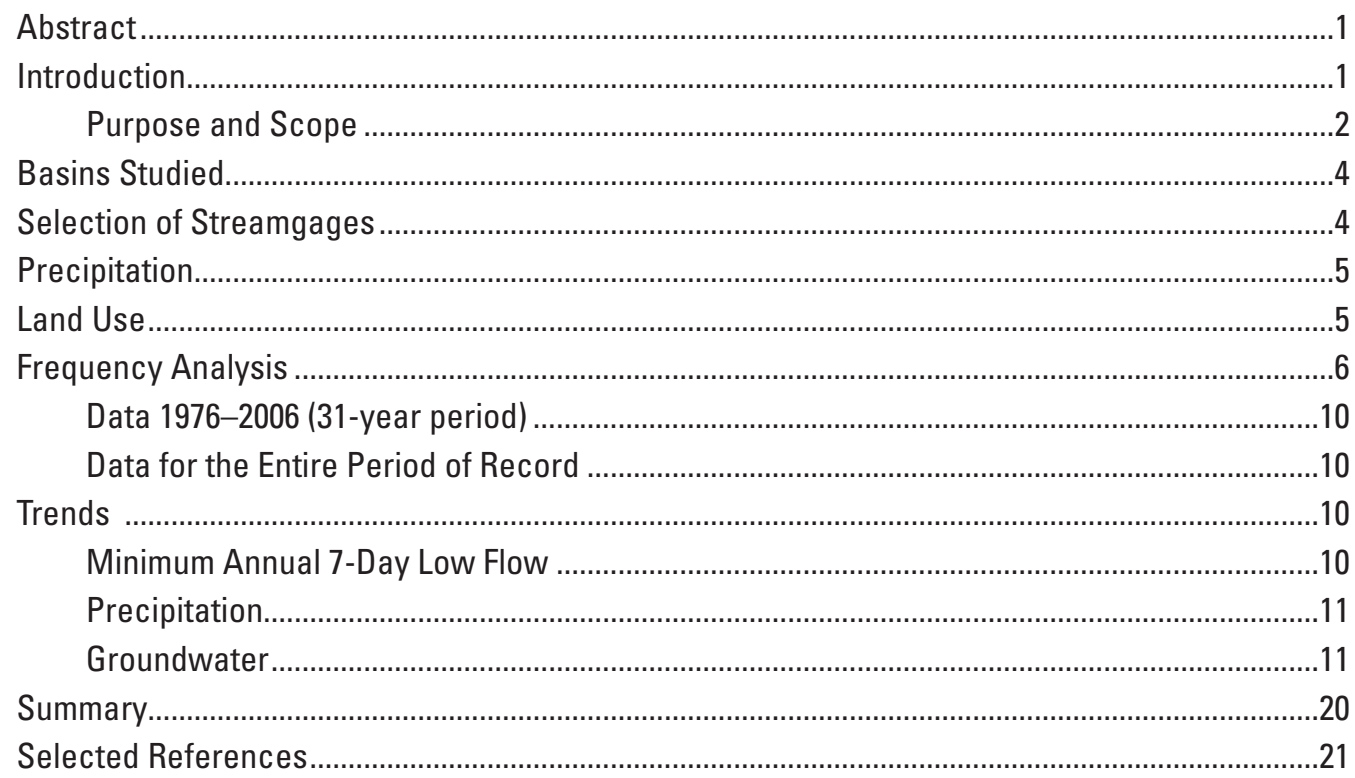

\section{Figures}

1. Map showing locations of physiographic provinces of New York State drainage basins, U.S. Geological Survey (USGS) streamgages, Northeast Regional Climate Center (NRCC) precipitation stations, and groundwater wells referred to in this study.....

2. Graphs showing minumum annual 7-day low flow discharges and Kendall tau trend for eight streamgages in New York State.

3. Graphs showing annual precipitation from 1961 to 2006 and Kendall tau trend at selected Northeast Regional Climate Center precipitation stations in New York

4. Graphs showing departure of total annual precipitation at selected Northeast Regional Climate Center stations in New York State, from the 30-year average (1961-90), in inches

5. Thirty-year average (1976-2006) hydrographs of weekly water levels at selected U.S. Geological Survey (USGS) groundwater observation wells in New York.

\section{Tables}

1. Northeast Regional Climate Center station name, number, location, elevation, and 30-year average annual precipitation (1961-1990) for climate records analyzed in this study.

2. Consolidation classes for U.S. Geological Survey (USGS) Geographic Information Retrieval and Analysis System (GIRAS) and National Land Cover Database 2001 (NLCD 2001) classes used in this study... 
3. Indicated percent change in land use or land cover from 1970 through 2003 as a percent of drainage basins for eight streamgages in New York (N.Y.)

4. Estimated 7-day, 2-year and 10-year low-flow frequency discharges for eight streamgages in New York (N.Y.) computed from log-Pearson type III analysis and compared with estimated low-flow frequency discharges published in Bulletin 74

5. Selected data for three observation wells in the U.S. Geological Survey observation-well network in New York State

\section{Conversion Factors, Datum, and Acronyms}

\begin{tabular}{lcl}
\hline \multicolumn{1}{c}{ Multiply } & By & \multicolumn{1}{c}{ To obtain } \\
\hline inch (in.) & Length & \\
inch (in.) & 2.54 & centimeter $(\mathrm{cm})$ \\
foot (ft) & 25.4 & millimeter $(\mathrm{mm})$ \\
mile (mi) & 0.3048 & meter $(\mathrm{m})$ \\
\hline \multicolumn{3}{c}{} \\
\hline square mile $\left(\mathrm{mi}^{2}\right)$ & 1.609 & kilometer $(\mathrm{km})$ \\
\hline & Area & \\
\hline cubic foot per second $\left(\mathrm{ft}^{3} / \mathrm{s}\right)$ & 2.590 & square kilometer $\left(\mathrm{km}^{2}\right)$ \\
\hline
\end{tabular}

Temperature in degrees Celsius $\left({ }^{\circ} \mathrm{C}\right)$ may be converted to degrees Fahrenheit $\left({ }^{\circ} \mathrm{F}\right)$ as follows:

$$
{ }^{\circ} \mathrm{F}=\left(1.8 \times^{\circ} \mathrm{C}\right)+32
$$

Temperature in degrees Fahrenheit $\left({ }^{\circ} \mathrm{F}\right)$ may be converted to degrees Celsius $\left({ }^{\circ} \mathrm{C}\right)$ as follows:

$$
{ }^{\circ} \mathrm{C}=\left({ }^{\circ} \mathrm{F}-32\right) / 1.8
$$

Vertical coordinate information is referenced to North American Vertical Datum of 1988 (NAVD 88).

Horizontal coordinate information is referenced to North American Datum of 1983 (NAD 83).

Elevation, as used in this report, refers to distance above the vertical datum. 


\section{Acronyms Used in Report}

$\begin{array}{ll}\text { CLIMOD } & \text { Climate Information for Management and Operational Decisions } \\ \text { EROS } & \text { Earth Resource Observation Systems } \\ \text { GIRAS } & \text { USGS Geographic Information Retrieval and Analysis System } \\ \text { MA7CD2 or 702 } & \text { Minimum average 7-day 2-year discharge } \\ \text { MA7CD10 or 7010 } & \text { Minimum average 7-day 10-year discharge } \\ \text { NEGA-RASA } & \text { Northeast Glacial Aquifers Regional Aquifer-System Analysis project } \\ \text { NLCD } & \text { National Land Cover Database } \\ \text { NRCC } & \text { Northeast Regional Climate Center } \\ \text { NYSDEC } & \text { New York State Department of Environmental Conservation } \\ \text { TMDL } & \text { Total maximum daily loads } \\ \text { USGS } & \text { U.S. Geological Survey } \\ \text { WM0 } & \text { World Meteorological Organization }\end{array}$


This page has been left blank intentionally. 


\title{
Changes in Low-Flow Frequency 1976-2006 at Selected Streamgages in New York, Excluding Long Island
}

\author{
By Thomas P. Suro and Christopher L. Gazoorian
}

\section{Abstract}

Many Federal, State, and local agencies use low-flow data to establish water-use policy and help determine the total maximum daily loads and effluent limits of point and nonpoint sources of contamination of surface water during periods of decreased streamflow. Low-flow magnitude and frequency are used often by water-supply planners, reservoir managers, and hydroelectric facilities to manage water availability for supply and power generation.

Low-flow statistics for eight selected U.S. Geological Survey streamgages in New York State were calculated for the period from 1976 through 2006 and for the entire period of continuous streamflow record. The 7-day, 2-year and 10-year low flows were computed and compared with those low flows published in the1979 U.S. Geological Survey report, Lowflow frequency analysis of streams in New York, Bulletin 74. Observed changes in low-flow frequency at each gage were then examined and compared to changes in precipitation and land use to determine whether a relation between similar patterns could be identified.

A statewide U.S. Geological Survey study has not been done to develop equations for estimating low flows on rural unregulated streams in New York. Currently (2010) only one regional study developed for parts of the lower Hudson River Basin in 1986 is available to assist in estimating low flows on rural streams with unregulated streamflow in New York. Lowflow statistics published in the 1979 report need to be updated by using additional data collected since 1976 to determine current low-flow conditions across New York State.

At-site low-flow statistics were updated for eight streamgages in New York by using continuous daily streamflow data through 2006 for the future development of a statewide research study. Selection of the eight streamgages used in this study identified a major deficiency in the number of available unregulated long-term U.S. Geological Survey streamgages needed for the development of regional low-flow equations in New York. A limited analysis of the changes in land use for the contributing drainage areas for each streamgage, changes in precipitation, and trends in the annual 7-day minimum flow also are presented. The 7-day, 2-year low flow showed increases of 14 to 35 percent and the 7-day 10 -year low flow showed zero to 19 percent increases at rural streamgages with unregulated streamflows when statistics were computed by using data from 1976 through 2006 and compared with published data in Bulletin 74. When the entire period of record was used to compute low flow frequencies, the 7-day, 2-year low flows increased from about 6 to 15 percent whereas the 7-day 10-year low flows showed zero to 5 percent increases. Streamgages affected by urbanization and regulation for water supply showed the most significant changes in the 7-day, 2-year and 10-year low-flow frequencies. These streamgages are included to help identify the effects of urbanization and regulation on streamflow at these locations. The 7-day 10-year low flow increased by 65 percent at the U.S. Geological Survey streamgage Hackensack River at West Nyack, N.Y., and increased 120 percent at the U.S. Geological Survey streamgage Neversink River at Godeffroy, N.Y., when statistics were computed by using data from 1976 through 2006 and compared with the statistics for the regulated period computed in Bulletin 74.

\section{Introduction}

Severe drought conditions in the southeastern United States have emphasized the need for improved estimates of low-flow frequency and magnitude. Drought watches and warnings have been issued for the New York City water supply three times since 1989. A Stage III Emergency was declared in 1989 and the Chelsea Pumping Station was activated to draw water from the Hudson River (New York City Department of Environmental Protection, 2007). During the fall of 1995 the water supply in the New York City reservoir system dropped to 51 percent of capacity (Lumia, 1998). A Stage I Emergency was declared in 2002 when the supply system dropped to 41.5 percent of storage capacity.

An extended period of low flows on the Hudson River in 1995, 1999, and 2001, combined with other factors that allowed salt water to move upstream to Poughkeepsie more than 73 miles upstream from the mouth of the Hudson River, affecting drinking-water withdrawals from the river. Many 


\section{Changes in Low-Flow Frequency 1976-2006 at Selected Streamgages in New York, Excluding Long Island}

Federal, State and local permitting and regulatory agencies use low-flow data to establish policy on withdrawals from and effluent discharge into streams. These data also are vital for determining the total maximum daily loads (TMDL) and effluent limits of point and nonpoint sources of contamination of surface water during sustained periods of decreased streamflow. Water-supply planners and managers of reservoirs and hydroelectric facilities often use low-flow statistics to manage water availability for supply and generating power.

The U.S. Geological Survey (USGS) has been collecting surface-water data in New York State for more than 100 years, but the systematic use of low-flow partialrecord stations did not begin until the 1950s, and increased in number as a result of the drought during the 1960s. The USGS, in cooperation with the New York Department of Environmental Conservation (NYSDEC) completed a study in 1979 that computed at-site low-flow statistics for 154 streamgages (146 in New York State) with unregulated streamflow and 124 streamgages (122 in New York State) with regulated streamflow in New York and the surrounding area (Eissler, 1979). This study also computed low-flow statistics for 648 low-flow partial-record stations in New York and the surrounding area. Low-flow statistics for the streamgages published in the 1979 report were computed directly from approved daily streamflow data, but the period of available record for many of these streamgages was less than 20 years, ranging from the mid-1950s (or early 1960s) through 1975. Since 1976, many of these streamgages have been discontinued, and the network of low-flow partial-record stations no longer exists. However, many streamgages that have been in continuous operation since the 1979 report now have an additional 31 years of data (through 2006) that if analyzed could provide updated low-flow statistics. Low-flow statistics published in the 1979 report need to be updated by using these additional data since 1976 to determine current (2010) low-flow conditions throughout New York State.

The USGS has not done a statewide study to develop equations for estimating low flows on rural unregulated streams in New York. Only one outdated regional study is available for use in estimating low flows on rural streams with unregulated streamflow in New York. Barnes (1986) developed a method for estimating low-flow statistics for ungaged streams in parts of the Lower Hudson River basin. This method related the 7-day, 2-year and 10-year low flows to selected basin characteristics by multiple-regression analysis for 53 continuous and partial-record streamgages having watershed areas of less than 100 square miles $\left(\mathrm{mi}^{2}\right)$. A study of low flows in the Susquehanna River basin (Randall, 2010) was done in the mid-1980s as part of the Northeast Glacial Aquifers Regional Aquifer-System Analysis project (NEGA-RASA). This study updated a previous study of the Susquehanna River basin (Ku and others, 1975). The 1975 report presented at-site determinations of low-flow statistics but did not include methods for estimating lowflow magnitude and frequency at ungaged streams in the Susquehanna River basin.
A thorough analysis of the USGS streamgage network in New York State would help determine the effectiveness of the current (2010) network and whether the network is sufficient to adequately define regional equations to estimate low flows at rural unregulated streams in New York. A network analysis can help determine individual station contributions to defining regional low-flow equations and predicting lowflow statistics at ungaged streams. These data would help to determine whether the current network should be expanded by reactivating discontinued streamgages or partial-record stations that could provide more valuable data and improve the accuracy of regional low-flow equations.

In cooperation with NYSDEC, the USGS has updated at-site low-flow statistics for eight streamgages in New York by using continuous daily streamflow data through 2006 (fig. 1). This report presents a limited analysis of the changes in land use for the contributing drainage areas for each streamgage; the changes in precipitation and the trends in the annual 7-day minimum flow are presented in this report to offer possible explanations for changes identified in the newly computed low-flow statistics. The eight streamgages have a contributing drainage area that lies in all or parts of six of the eight physiographic regions in New York, excluding Long Island. The minimum average 7-day, 2-year discharge (MA7CD2) and the minimum average 7-day 10-year discharge (MA7CD10) were calculated by using two datasets: data from the entire period of continuous streamflow record and data from 1976 through 2006. These low-flow statistics are commonly referred to as the 7-day, 2-year and 10-year low flows. This report abbreviates the MA7CD2 as the "7Q2" and the MA7CD10 as the "7Q10." The newly computed low-flow frequency discharges were then compared with the statistics published in Bulletin 74 (Eissler, 1979). Changes in climate since the 1970s and the availability of 31 years of additional data at many locations emphasizes the need to update lowflow statistics published in $\mathrm{Ku}$ and others (1975) and Eissler (1979) to determine current (2010) low-flow conditions and to assist in developing a research study to create regional equations for estimating low flows on rural unregulated streams in New York.

\section{Purpose and Scope}

The purpose of this report is to provide updated statistics to help determine whether a statewide study that uses data through the 2006 climatic year (April 1 through March 31) would provide a better understanding of the current low-flow conditions and changes in low-flow frequency. This report also presents a means for inventorying the number of streamgages that remain active throughout New York State, excluding Long Island, with a complete period-of-record dataset since these stations were utilized in a low-flow study over 30 years ago. In 1979 the USGS published "Low-flow Frequency Analysis of Streams in New York" (Eissler, 1979), commonly referred to as the Bulletin 74 report. This report evaluated data collected 


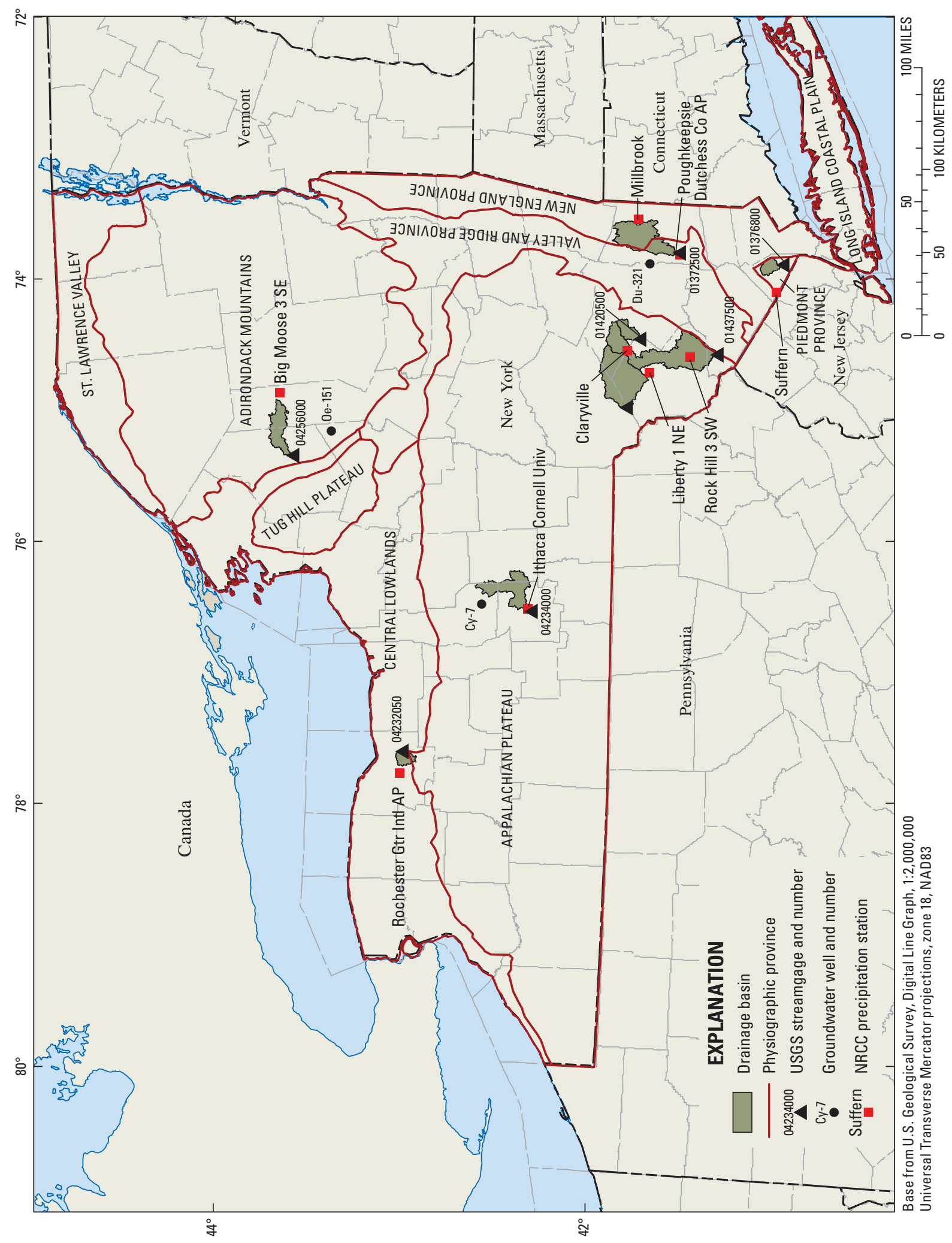

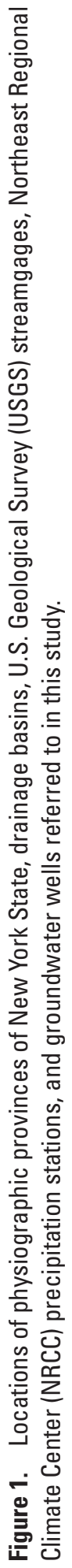




\section{Changes in Low-Flow Frequency 1976-2006 at Selected Streamgages in New York, Excluding Long Island}

prior to 1975 and provided data for 278 streamgages, of which 154 were on unregulated streams (146 in New York State) and 124 (122 in New York State) were on regulated streams, data for 648 low-flow partial-record streamgages, and data for 2,384 miscellaneous sites. The main focus of Bulletin 74 was to present statistical data for the 7-day, 2-year and 7-day 10 -year low flow at selected streamgages and at low-flow partial-record sites. The 7-day, 2-year and 7-day 10-year low flows are two of the most common low-flow statistics used by water-management agencies throughout New York State to assist in the planning and management of waste loads to streams, water-quality evaluations, water-supply design, groundwater management, and aquatic-habitat protection. Bulletin 74 has never been updated and regional equations for estimating low-flow statistics at unregulated streams throughout New York State have never been established.

This report is the first in a three-step process of developing methods to predict low-flow magnitude and frequency at rural unregulated sites in New York. The scope of this study was limited to the analysis of streamflow data at eight selected streamgages, and the presentation of data on land use, precipitation, and groundwater near these streamgages. The purpose of this first step is to investigate the hypothesis that low-flow statistics and the natural characteristics that strongly affect the statistics have changed throughout New York since the publication of Bulletin 74 in 1979. This study further seeks to briefly examine the changes in the estimated low-flow magnitude and frequency at these streamgages by comparing statistics computed that used data collected from 1976 through 2006 with the statistics published in the Bulletin 74 report (Eissler, 1979). Step two would compute low-flow statistics statewide, analyze the effectiveness of the current network, and suggest improvements to the network. Step three would develop regional or statewide equations for estimating low flows on rural unregulated streams in New York, excluding Long Island. Currently no plan exists for the implementation of steps two and three.

\section{Basins Studied}

New York State occupies all or part of nine physiographic provinces that differ widely, from the high-relief areas of the Adirondack and Catskill Mountains to the low-relief areas along the Great Lakes and in the valleys of the Hudson, Mohawk, and St. Lawrence Rivers (fig. 1). Long Island, which is excluded from the study area of this report, is located in the Coastal Plain province. The eight streamgages in this study have a contributing drainage area that lies in all or parts of six of eight physiographic regions, excluding Long Island (fig. 1). Although the selection criteria restricted the ability to select basins from all eight physiographic provinces, the six provinces included in this study represent many of the physical characteristics (slope, shape, and others) of basins found throughout New York State.

The St. Lawrence Valley province lies at the extreme northern border of New York and is primarily smooth glacial plain. The Adirondack province lies in the northern part of New York and covers an area of about 10,000 $\mathrm{mi}^{2}$. The western half of the province is a plateau and has an abundance of lakes and ponds, whereas the eastern half is mostly mountainous. The northern part of western New York lies in the Central Lowlands whereas most of the central and southern areas of western New York are in the Appalachian Plateau province. The Appalachian Plateau province is mostly hilly terrain with the highest elevations being in the Allegheny and Catskill Mountains. The area of New York east of Lake Ontario and west of the Adirondack Mountains province is classified as the Tug Hill Plateau province. The provinces in southeastern New York are the Valley and Ridge province, the New England province, and the Piedmont province.

\section{Selection of Streamgages}

This study initially considered most of the 146 streamgages on unregulated streams and the 124 on regulated streams in New York presented in Bulletin 74 (Eissler, 1979) that had a continuous uninterrupted record. Only streamgages with continuous records collected at the same location for which low-flow statistics were computed for Bulletin 74 were considered. This criterion prohibited sampling drainage basins smaller than $29 \mathrm{mi}^{2}$. Additionally, the proximity of each basin to a precipitation station with a continuous record through the same study period (1976-2006) was assessed. Only eight streamgages were selected because of the limited scope of the study; five of the streamgages are in unregulated basins and three are affected by some degree of regulation. Ideally only unregulated basins are selected when computing statistical data; however, some regulated basins were included to reflect urban drainages, most of which are subject to some regulation. All urban streamgages included in Bulletin 74 (Eissler, 1979) with a period of continuous record through the 2006 climatic year are regulated.

Only 53 of the 146 streamgages on unregulated streams in New York published in Bulletin 74 (Eissler, 1979) are still active with a continuous period of record. Geographic location, period of continuous record, percentage of drainage basin regulated, and urbanization were major factors in selecting the eight streamgages analyzed in this study. The Rondout Creek, Neversink River, and Beaver Kill streamgages are located in the Catskill Mountain region of New York. The Rondout Creek near Lowes Corners and Beaver Kill at Cooks Falls streamgages have long uninterrupted periods of record: 69 years of data at Rondout Creek, and 93 years of data at Beaver Kill were used in the analysis. These basins on the eastern and western slopes of the Catskill Mountain region are in areas that remain predominately rural with minimal 
development in the past 30 years. The Neversink River at Godeffroy streamgage also has a long period of record, but the record was split into regulated and unregulated when the Neversink Reservoir began storage operations in 1953. This station allows for the unique ability to compare 16 years of unregulated record and 22 years of regulated data published in Bulletin 74 (Eissler, 1979) with the conditions in 2006 to illustrate the effects of regulation on the streamflow. The Fall Creek and Allen Creek streamgages are in the Appalachian Plateau and Central Lowlands regions of western New York. The Fall Creek streamgage has an 81-year period of continuous record and is located on an unregulated stream. Allen Creek near Rochester has 45-year period of record, the shortest of the sites studied, and is located in an urbanized area. The Independence River at Donnattsburg streamgage is at the western border of the Adirondack Mountain region adjacent to the Tug Hill Plateau, and the Wappinger Creek and Hackensack River streamgages are in the New England province of New York. The Wappinger Creek streamgage has a 77-year period of unregulated streamflow and a contributing drainage basin that is sparsely urbanized. The Hackensack River at West Nyack streamgage is in a highly urbanized area and has regulated streamflows from Deforest Lake with diversions from the streamgage pool for municipal supply. These streamgages were included for analysis to allow for the comparison with statistics computed from Bulletin 74 (Eissler, 1979) to examine trends in urban areas and changes in patterns of regulation. Urbanization and development generally increase the area of impermeable land surface, the tunneling of small creeks and streams and the demand for water supply. In general, increases in the area of impermeable land surface and the increased demand for water supply can lead to larger spikes in runoff during wet periods and have a greater effect on low flows during dry periods.

\section{Precipitation}

The climate of New York State is classified as humid continental, the prevailing climate type in the northeastern United States. General climatic conditions in New York are controlled by the usual path of air mass movement in relation to the location of the State. Generally, cool and dry air masses move eastward across New York throughout the year. Warm and humid tropical air masses usually move northeastward from the south during the summer months.

The locations of the National Weather Service precipitation stations used in this report are shown in figure 1. Table 1 lists the name and site number, location, elevation, and 30-year (1961-1990) average precipitation for each station. The criteria for selecting these stations were continuity and length of record, minimal amount of estimated daily data by Climate Information for Management and Operational Decisions (CLIMOD), and proximity to one of the USGS streamgages analyzed in this study. Precipitation data for two precipitation stations in Dutchess County were combined to produce a continuous dataset for analysis. The record for Millbrook was used through 2000, when the station was discontinued. Data from 2001 through 2006 for the Poughkeepsie Dutchess County Airport was substituted for the missing Millbrook record to produce a single 30-year period of data. These two stations are fairly well correlated $\left(\mathrm{R}^{2}=0.69\right.$ for the period 1949-1992) and are in close proximity and close to the Wappinger Creek at Wappingers Falls streamgage. The 30-year mean annual precipitation for Millbrook was computed by using the combined dataset.

The 30-year average annual precipitation for the period 1961-1990 for these sites ranged from 31.96 inches (in.) in Monroe County at the Greater Rochester International Airport to 50.56 in. at Claryville in Sullivan County and 50.36 in. at Big Moose SE in Herkimer County. Total annual precipitation at these sites ranged from about 22 to $69 \mathrm{in}$. for the 30 -year period from 1961 through 1990 (Northeast Regional Climate Center, 2008).

\section{Land Use}

The USGS Geographic Information Retrieval and Analysis System (GIRAS) was used as a reference for identifying land use and land cover characteristics in 1979 and 1984 (U.S. Geological Survey, 1979a, 1979b, 1984a, 1984b) for the contributing drainage area of the eight USGS streamgages analyzed in this study. GIRAS is a digital database of land use and land cover compiled from USGS 1:250,000 scale maps created in the 1970s and 1980s. These data were compared to land use and land cover data from the National Land Cover Database (NLCD) 2001, which are derived from Landsat satellite imagery representing land cover of the study basins in 2001 (U.S. Geological Survey, 2003). The NLCD 2001 was assumed to represent current landcover conditions.

Although comparisons between the GIRAS and NLCD datasets are difficult and uncertain, the decision was made to rely on GIRAS because of the inability to identify historical data of higher quality. The GIRAS and NLCD datasets use different scales and classification methods to interpret landuse and land-cover data. The differences in methodology resulted in overlapping classes that may have lead to misclassifying land cover in the GIRAS dataset, thereby creating inconsistencies between the datasets. The Landsat satellite imagery used for the NLCD is able to identify landuse boundaries at a much smaller scale and, therefore, allow conceptually clearer classifications. The historical GIRAS dataset is based on 22 classes of land use including an "Other" class whereas the NLCD 2001 dataset is based on 16 classes. Some GIRAS classes were eliminated or consolidated because they were considered unnecessary or redundant in the NLCD 2001 classification scheme, and other classes were expanded into several more specific NLCD classes. Although the NLCD 


\section{Changes in Low-Flow Frequency 1976-2006 at Selected Streamgages in New York, Excluding Long Island}

Table 1. Northeast Regional Climate Center station name, number, location, elevation, and 30-year average annual precipitation (1961-1990) for climate records analyzed in this study.

[Station names are listed in table exactly as they appear on the Northeast Regional Climate Center data page. SE, southeast; Univ, University; NE, northeast; Gtr, Greater; Intl, International; AP, Airport; SW, southwest; Co, County]

\begin{tabular}{|c|c|c|c|c|c|}
\hline $\begin{array}{l}\text { Northeast Regional } \\
\text { Climate Center } \\
\text { station name }\end{array}$ & $\begin{array}{l}\text { Station } \\
\text { number }\end{array}$ & $\begin{array}{l}\text { Latitude } \\
\text { (degrees) }\end{array}$ & $\begin{array}{l}\text { Longitude } \\
\text { (degrees) }\end{array}$ & $\begin{array}{c}\text { Elevation } \\
\text { (feet) }\end{array}$ & $\begin{array}{c}\text { 30-year } \\
\text { average } \\
\text { precipitation } \\
(1961-90), \\
\text { in inches }\end{array}$ \\
\hline Big Moose $3 \mathrm{SE}$ & 300668 & 43.80 & 74.87 & 1,760 & 50.36 \\
\hline Ithaca Cornell Univ & 304174 & 42.45 & 76.45 & 960 & 35.40 \\
\hline Liberty $1 \mathrm{NE}$ & 304731 & 41.80 & 74.73 & 1,549 & 48.29 \\
\hline Rochester Gtr Intl AP & 307167 & 43.12 & 77.68 & 533 & 31.96 \\
\hline Rock Hill 3 SW & 307205 & 41.58 & 74.62 & 1,270 & 46.28 \\
\hline Suffern & 308322 & 41.11 & 74.16 & 270 & 49.32 \\
\hline Millbrook & 305334 & 41.85 & 73.62 & 820 & 40.65 \\
\hline Poughkeepsie Dutchess Co AP & 306820 & 41.63 & 73.88 & 166 & 40.72 \\
\hline Claryville & 301521 & 41.92 & 74.57 & 1,653 & 50.56 \\
\hline
\end{tabular}

2001 has fewer classes the dataset better defines the different impacts that various land uses have on physical characteristics of the land than does GIRAS. Analysis of both datasets resulted in a decision to develop seven consolidation classes of land use to allow for the comparison of the two datasets even though several land-cover and land-use classes were consolidated into a single class. The consolidation scheme is outlined in table 2.

The seven consolidation classes and the estimated percentage of change in total area for each basin are listed in table 3. An increase in developed area and a decrease in agricultural and forest areas are indicated for most of the basins. The indicated increase in developed area was less than 8 percent for most sites, except for Allen Creek near Rochester, which indicated a nearly 13-percent increase. A minor decrease in forested area was identified at the three sites in the Catskill Mountain region (Rondout Creek near Lowes Corners, Beaver Kill at Cooks Falls, and Neversink River at Godeffroy), but relatively large decreases of 31.4 percent in the Independence River basin and 39.1 percent in the Fall Creek basin of northern and western New York were identified. A 21-percent increase in wetland areas in the Independence River basin is paired with a 31-percent decrease in forested area in the basin, but this may be caused by differences in the GIRAS and NLCD classification schemes and not an actual change of the land cover. An alternative theory suggests that the 21-percent increase in wetland areas was a reclassification of some forested area so that the resultant difference of about 10 percent might be a better estimate of the actual decrease in forested areas. The increase in agricultural land in the Fall Creek basin may be fairly reliable, primarily because of recently increased dairy production (Johnson and others, 2007). An apparent increase in the percentage of wetlands and a decrease in forested area in many basins do not seem consistent with the apparent increased development and decreased agriculture in those areas. As was suggested for similar data in the Independence River basin, the GIRAS dataset may have misclassified some wetlands as forest.

\section{Frequency Analysis}

Streamflow at a streamgage is affected by many natural factors including climate, geomorphology of the channel, geology, and groundwater levels. Human activities such as building reservoirs and dams, and making withdrawals from surface-water and groundwater systems for municipal and industrial use also affect streamflow.

Low-flow statistics are usually computed by using continuous record from streamgages having a period of record of 10 years or greater. Daily mean discharge values are used to compute the lowest mean discharge for a series of consecutive days for each year. The USGS generally computes annual discharge statistics on a water-year basis (October 1 to September 30), but low-flow discharge statistics are computed by using an annual period called a climatic year (April 1 to March 31) because the annual low-flow period is usually during the late summer and fall. A climatic year includes the 
Table 2. Consolidation classes for U.S. Geological Survey (USGS) Geographic Information Retrieval and Analysis System (GIRAS) and National Land Cover Database 2001 (NLCD 2001) classes used in this study.

\begin{tabular}{|c|c|c|}
\hline GIRAS class & Consolidation class & NLCD 2001 class \\
\hline 0 - Other & Developed & 21 - Developed, open space \\
\hline 11 - Residential & & 22 - Developed, low intensity \\
\hline 13 - Industrial & & 24 - Developed, high intensity \\
\hline \multicolumn{3}{|l|}{14 - Transportation, communications and utilities } \\
\hline \multicolumn{3}{|l|}{16 - Mixed urban or built-up land } \\
\hline \multicolumn{3}{|l|}{17 - Other urban or built-up land } \\
\hline 21 - Cropland and pasture & Agricultural & 81 - Pasture/hay \\
\hline 22 - Orchard, grove, vineyard, nursery and ornamental horticultural areas & & 82 - Cultivated crops \\
\hline \multirow[t]{2}{*}{32 - Shrub and brush rangeland } & Scrub/ shrub & $52-$ Scrub/ shrub \\
\hline & & 71 - Grassland/herbaceous \\
\hline 41 - Deciduous forest land & Forest & 41 - Deciduous forest \\
\hline 42 - Evergreen forest land & & 42 - Evergreen forest \\
\hline 43 - Mixed forest land & & 43 - Mixed forest \\
\hline 52 - Lakes & Open water & 11 - Open water \\
\hline 76 - Transitional areas & & \\
\hline
\end{tabular}

entire period April 1 to March 31, but by using a water year for analysis would separate the sustained low-flow period between 2 years.

An often used low-flow series is the minimum average 7-consecutive-day flow. Many State and local agencies use a frequency statistic computed by using an annual 7-consecutive-day series to assist them in making regulatory decisions. The minimum average 7-consecutive-day low flow is computed for each climatic year of data available. A log Pearson Type III frequency distribution is then computed to determine the low-flow statistics at selected streamgages. Frequency analysis of the annual 7-day low flows provides a means for estimating the probability of occurrence of a given discharge. Low-flow frequency commonly is referred to in terms of recurrence interval or the probability of being exceeded (one is the reciprocal of the other). The minimum average 7-day 10-year low-flow discharge (7Q10), for example, has a probability of 0.1 (10 percent chance) of not being equaled or exceeded in any given year.

The minimum average 7-day, 2-year (7Q2) and 7-day 10-year (7Q10) low-flow statistics were computed for all eight streamgages in this report by using the full period of record available for each streamgage, data for the period from 1976 through 2006 (31-year period), and data from 1997 through 2006 (10-year period). These values were then compared with the values determined in Bulletin 74 (Eissler, 1979). These values are listed in table 4. 


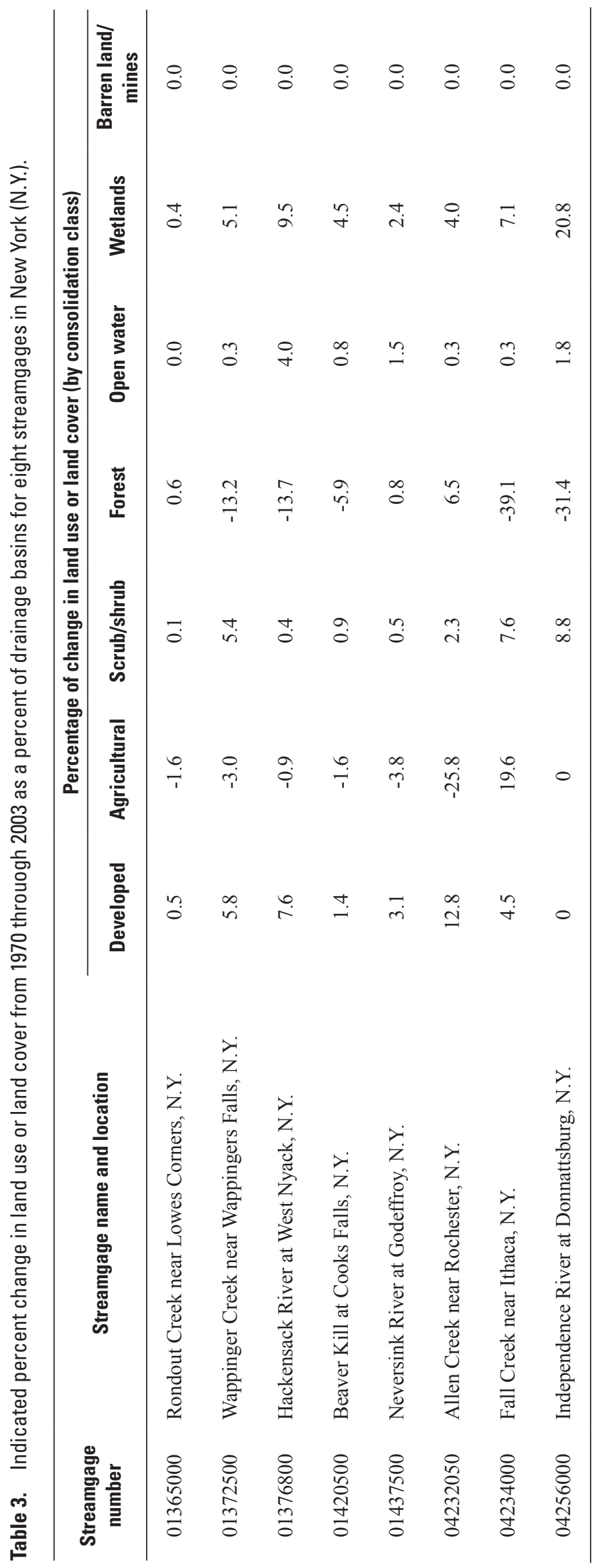




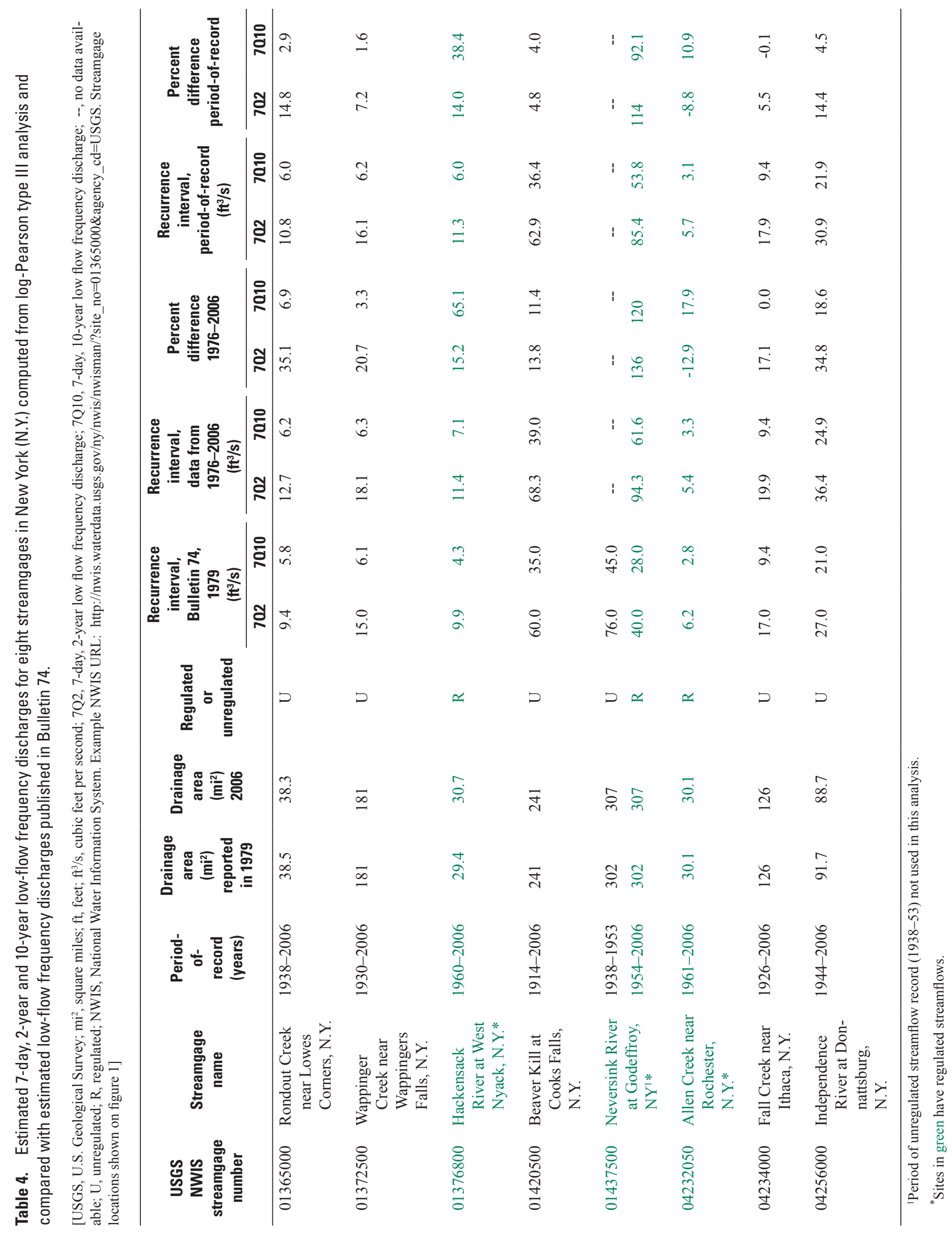




\section{Data 1976-2006 (31-year period)}

The 7Q10 discharges computed by using the 31 years (1976 through 2006) of data collected from the eight streamgages collected since the Bulletin 74 statistics (Eissler, 1979) indicated changes ranging from no decrease to about 19 percent increase at streamgages on unregulated streams when compared with discharges published in Bulletin 74 (Eissler, 1979). The 7Q2 discharges computed by using data from 1976 through 2006 indicated that all sites increased from 14 to 35 percent at streamgages on unregulated streams when compared with the discharges in Bulletin 74 (Eissler, 1979).

The 7Q10 for Wappingers Creek near Wappingers Falls and Rondout Creek near Lowes Corners, indicate increases of about 3 to 7 percent, whereas the computed 7Q10 for Fall Creek near Ithaca, indicated zero change. The 7Q10 for Beaver Kill at Cooks Falls and Independence River at Donnattsburg, indicated increases of 11.4 and 18.6 percent, respectively. The 7Q2 for all five of these streamgages show increases, with Rondout Creek and Independence River both showing the largest increases (35.1 and 34.8 percent, respectively) when compared with values computed for Bulletin 74 (Eissler, 1979).

Among the streamgages located in an urbanized area, the 7Q10 for those at Hackensack River at West Nyack and at Allen Creek near Rochester show an increase of 65.1 and 17.9 percent, respectively. Both streams are regulated upstream from the streamgages. Hackensack River diversions are used for municipal supply for the town of Nyack, and Allen Creek diversions are made during the operating season from the Erie Canal through sets of siphons upstream from the station and used for augmenting low flows and golf-course irrigation. The Hackensack River at West Nyack and the Allen Creek near Rochester streamgages are both located in urbanized areas; therefore, changes in the low-flow frequency may reflect changes in patterns of climate, urbanization, and regulation.

The data from Neversink River at Godeffroy indicate the largest increase of all streamgages, a result that is obvious in all computed statistics since the Neversink Reservoir began regulating streamflow in 1954 . The 7Q10 statistics for the Neversink River at Godeffroy streamgage indicate the largest increase (120 percent) when the statistics were computed by using data from 1976 through 2006 and when this value was compared with the statistics computed in Bulletin 74 (Eissler, 1979). This large increase in low-flow frequency may be partially attributed to changes in the release operations from Neversink Reservoir. The 7Q10 at Neversink River at Godeffroy computed by using data from 1976 through 2006 shows a 37-percent increase when compared with the 7Q10 computed in Bulletin 74 (Eissler, 1979) for the period before regulation, 1938-1953.

\section{Data for the Entire Period of Record}

Comparing statistics computed by using data for the entire period of record for unregulated sites indicated changes ranging from no decrease to a 4.5 percent increase in the computed 7Q10 when compared with data from Bulletin 74 (Eissler, 1979). The 7Q10 for Independence River at Donnattsburg and Beaver Kill at Cooks Falls indicated increases of 4.5 and 4.0 percent, respectively. The 7Q10 for Fall Creek near Ithaca indicated virtually no change when compared with data from Bulletin 74 (Eissler, 1979).

The 7Q10 for Hackensack River at West Nyack indicated a 38.4-percent increase, whereas 7Q10 for Allen Creek near Rochester streamgage indicated a 10.9 percent increase. The 7 Q10 for Neversink River at Godeffroy, regulated by releases from Neversink Reservoir, indicated the largest increase of 92.1 percent for the regulated period from 1954 through 2006.

The computed 7Q2 for the unregulated sites indicated increases ranging from 4.8 to 14.8 percent when compared with data from Bulletin 74 (Eissler, 1979). The 7Q2 for Rondout Creek near Lowes Corners and 7Q2 for Independence River at Donnattsburg indicated the largest increases of 14.8 and 14.4 percent, respectively. The 7Q2 for Wappingers Creek near Wappingers Falls streamgage indicated a 7.2 percent increase whereas the 7Q2 for Fall Creek near Ithaca indicated an increase of 5.5 percent.

The 7Q2 for Hackensack River at West Nyack and the Allen Creek near Rochester streamgages, located in urbanized areas with regulated streamflows, indicated an increase of 14.1 percent and a decrease of -8.8 percent, respectively, when compared with data from Bulletin 74 (Eissler, 1979).

\section{Trends}

\section{Minimum Annual 7-Day Low Flow}

The 7-day low-flow discharges computed for each of the streamgages that used the full period of record were analyzed by using Kendall's tau test (Helsel and Hirsch, 1992) to identify trends. The Kendall's tau test is a nonparametric test that can be used to identify trends in streamflow and precipitation data over time. A positive value for Kendall's tau indicates a positive trend and a negative tau indicates a negative trend. The $p$-value is the probability of obtaining a value of the tested data (7-day low flow) with equal magnitude to the observed extremes, assuming the null hypothesis is true. The trend was considered to be significant if the probability value ( $p$-value) was less than or equal to 0.05 . This value represents a 95-percent confidence level. 
Data from six of the streamgages tested showed a positive trend, one showed a negative trend, and one showed no trend when evaluating the entire period of record at each streamgage. Data from two of the streamgages, Independence River at Donnattsburg and Neversink River at Godeffroy, indicated a significant positive trend and data from Rondout Creek near Lowes Corners indicated a nearly significant positive trend. The annual 7-day low flows show an obvious pattern of increasing 7-day low flows beginning in the 1970s for six of the eight streamgages studied (fig. 2). The pattern is most obvious at the unregulated rural streamgages. Independence River, Rondout Creek, Wappinger Creek, and Fall Creek clearly illustrate this pattern. The annual 7-day low flows for the Wappinger Creek near Wappingers Falls streamgage were generally less than 30 cubic feet per second $\left(\mathrm{ft}^{3} / \mathrm{s}\right)$ during the 1930s through the late 1960s, but since about 1970 , the pattern generally seems to be increasing. Prior to 1970, only 2 years had annual 7-day low flows greater than $50 \mathrm{ft}^{3} / \mathrm{s}$, but since about 1970 , six of the annual 7-day low flows have been greater than $50 \mathrm{ft}^{3} / \mathrm{s}$. A similar pattern is visible at the Fall Creek near Ithaca streamgage. Prior to about 1975 , only one annual 7-day low flow was greater than about $30 \mathrm{ft}^{3} / \mathrm{s}$, but since 1975, seven annual 7-day low flows have been greater than $30 \mathrm{ft}^{3} / \mathrm{s}$. The minimum annual 7-day low flow for the period of record and the Kendall's tau trends for each streamgage are shown in figure 2.

\section{Precipitation}

Changes in precipitation patterns can cause changes in the minimum annual 7-day low flow. Precipitation data from eight National Weather Service stations located near the eight USGS streamgages were analyzed and Kendall's tau test was used to test for trends in the annual precipitation data for these stations. All eight stations showed a positive trend in annual precipitation. Three of the eight precipitation sites showed significant positive trends, and another two stations showed nearly significant positive trends. Annual precipitation from 1961 to 2006 for all eight stations is shown in figure 3, along with each Kendall tau trend. The World Meteorological Organization (WMO) defines normals as the average of climatological data computed for consecutive 30-year periods starting from January 1, 1901. A 30-year average (normal) of annual precipitation was computed by using data from 1961 through 1990 for each of these stations. Figure 4 shows the departure from this average during 1987-2006 (20 years). Seven of the precipitation stations showed a net positive departure from the 30-year average, whereas one station showed a decreasing departure from the 30 -year average. The largest positive change at many of the stations is most evident during the past 10 years (1997-2006) with the exceptions of Suffern and Big Moose 3 SE. The Liberty 1 NE station shows an increasing trend in annual precipitation, which included some of the largest annual precipitation totals occurring in the last 10 years when data from 1960 through 2006 were analyzed. This trend may be reflected in the 35.1-percent increase in the 7Q2 at the Rondout Creek near Lowes Corners streamgage when the 7Q2 is computed by using data since 1976 and compared with the 7Q2 value determined in Bulletin 74 (Eissler, 1979). The 7Q10 for Rondout Creek near Lowes Corners also shows a net increase of 6.9 percent when this statistic is computed using data since 1976 and compared with the 7Q10 determined for this streamgage in Bulletin 74 (Eissler, 1979).

A 2007 study (Burns and others, 2007) has determined that mean precipitation in the Catskill Mountain region has increased significantly by 136 millimeters per 50 years and that the annual mean air temperature has also increased $0.6^{\circ} \mathrm{C}$ per 50 years. Burns and others (2007) also reported that peak snowmelt is occurring earlier each year than in the past. It is possible that a smaller volume of water stored in snowpack later in the spring combined with changes in climate could affect low-flow frequency and magnitude in New York streams. Further analysis of climatic data throughout New York State would allow for greater insight into these types of changes.

\section{Groundwater}

The USGS operates a network of groundwater observation wells to meet several objectives such as monitoring the effects of climate change on long-term groundwater storage and the seasonal variability in recharge. Typically, the effects of climate change on groundwater levels would be best monitored by observation wells screened in major unconfined sand and gravel aquifers that are minimally affected by pumping or artificial recharge. The water level of these large unconfined aquifers is often referred to as "the water table" and changes in the elevation of the water table reflect seasonal and long-term changes in groundwater storage. Low-flow conditions throughout the State are influenced by many factors including the presence of large unconfined aquifers in the drainage basin of the gaged stream. Where a gaged stream crosses and is hydraulically connected to the aquifer, fluctuations in groundwater levels can help to explain changes in annual low flows. Unfortunately, many groundwater wells in the New York State network were discontinued in 1995 and not reactivated until 2000 to 2002. Data from three groundwater observation wells were included in this study as a simple means of identifying possible trends in groundwater levels in various regions of New York State. Two of the observation wells included in this study, CY-7 and OE-151, are in sand and gravel (water-table) aquifers. The third well, DU-321, is in a confined bedrock aquifer (fig. 5, table 5).

The wells in the sand and gravel aquifers were the nearest wells with 30 years of data to the selected USGS streamgages. The 30-year record at these wells shows a fairly constant level of groundwater storage, although a slight positive trend for CY-7 and a slight negative trend for OE-151 were identified. 

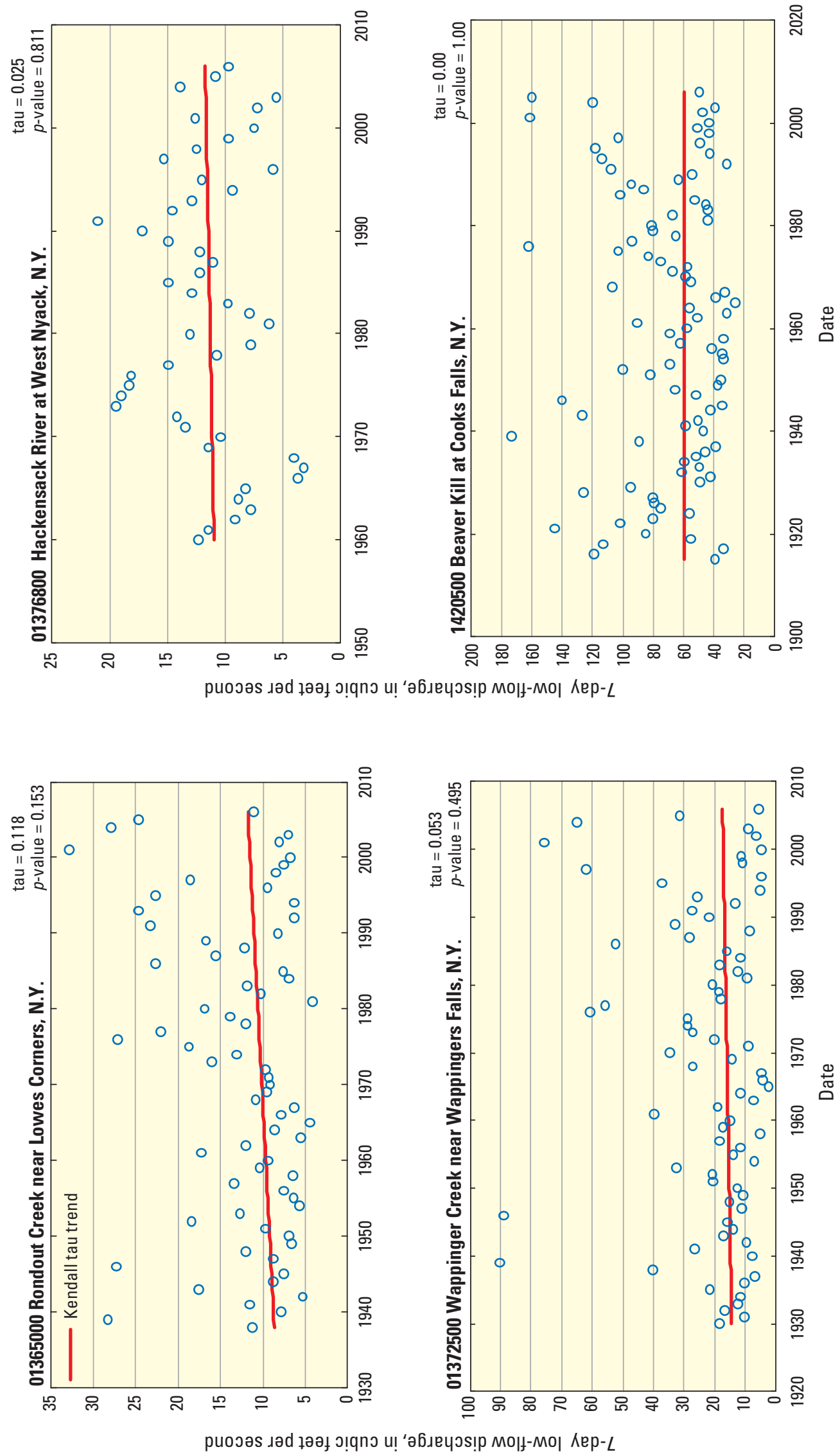

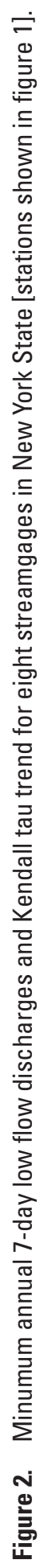



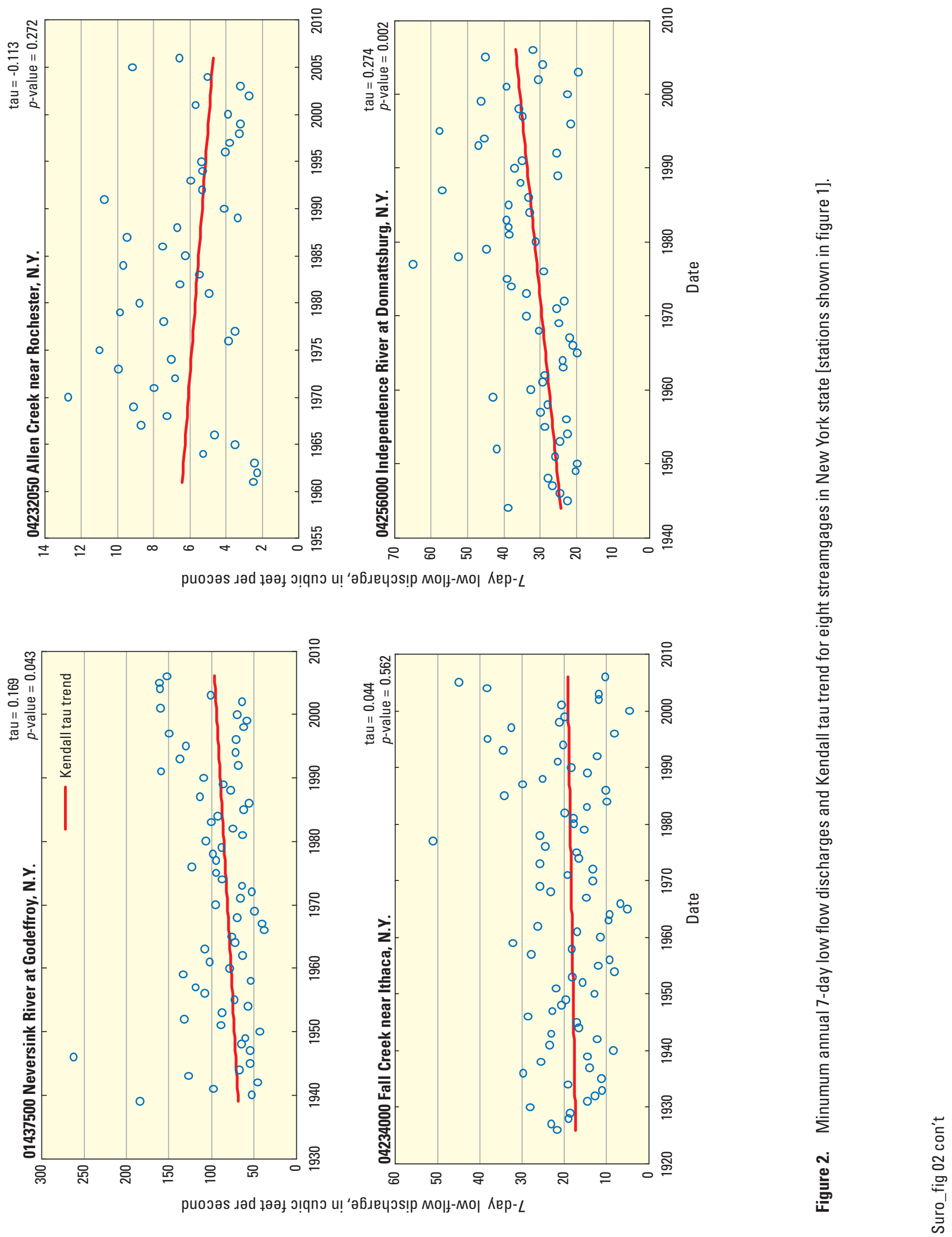

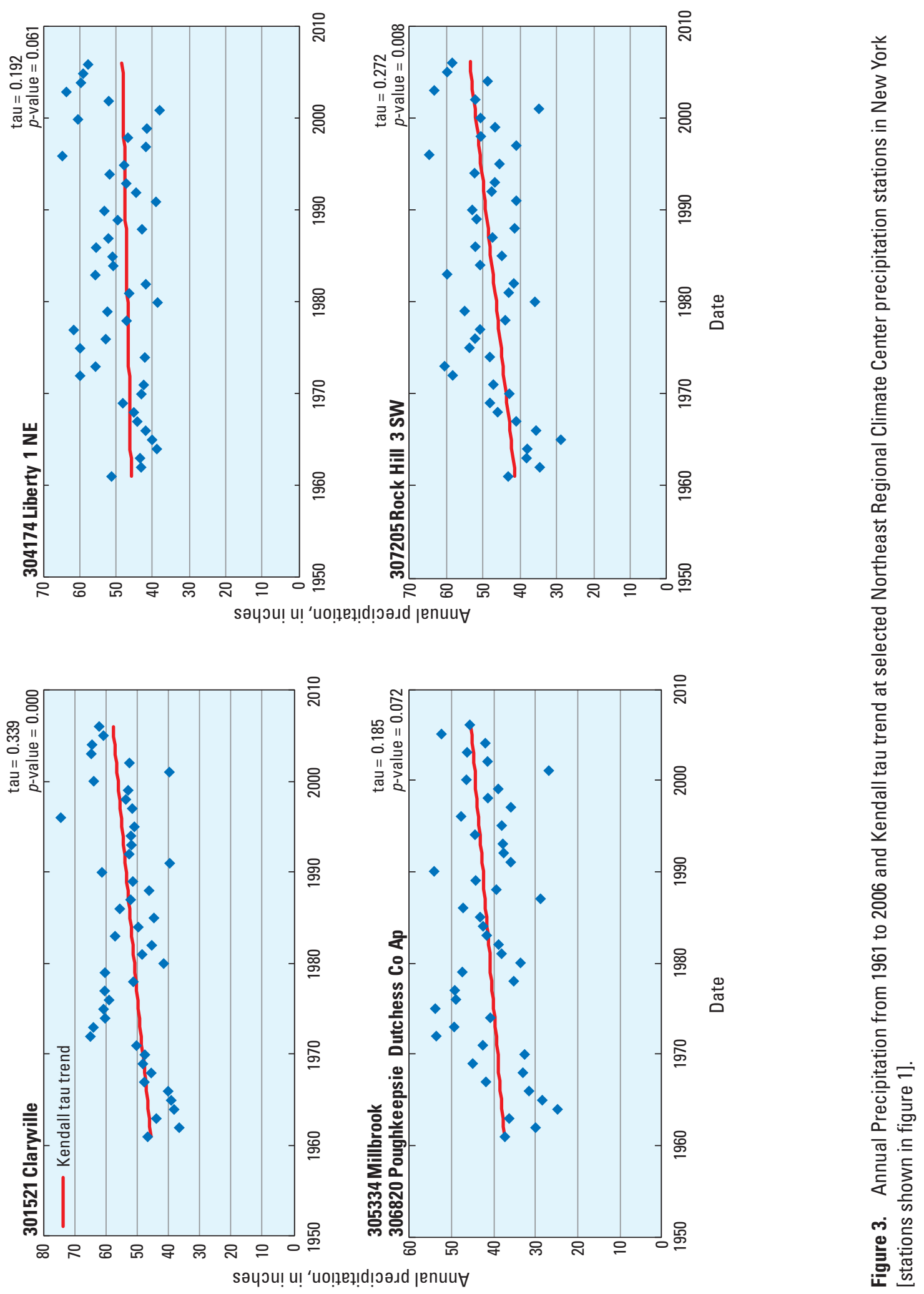

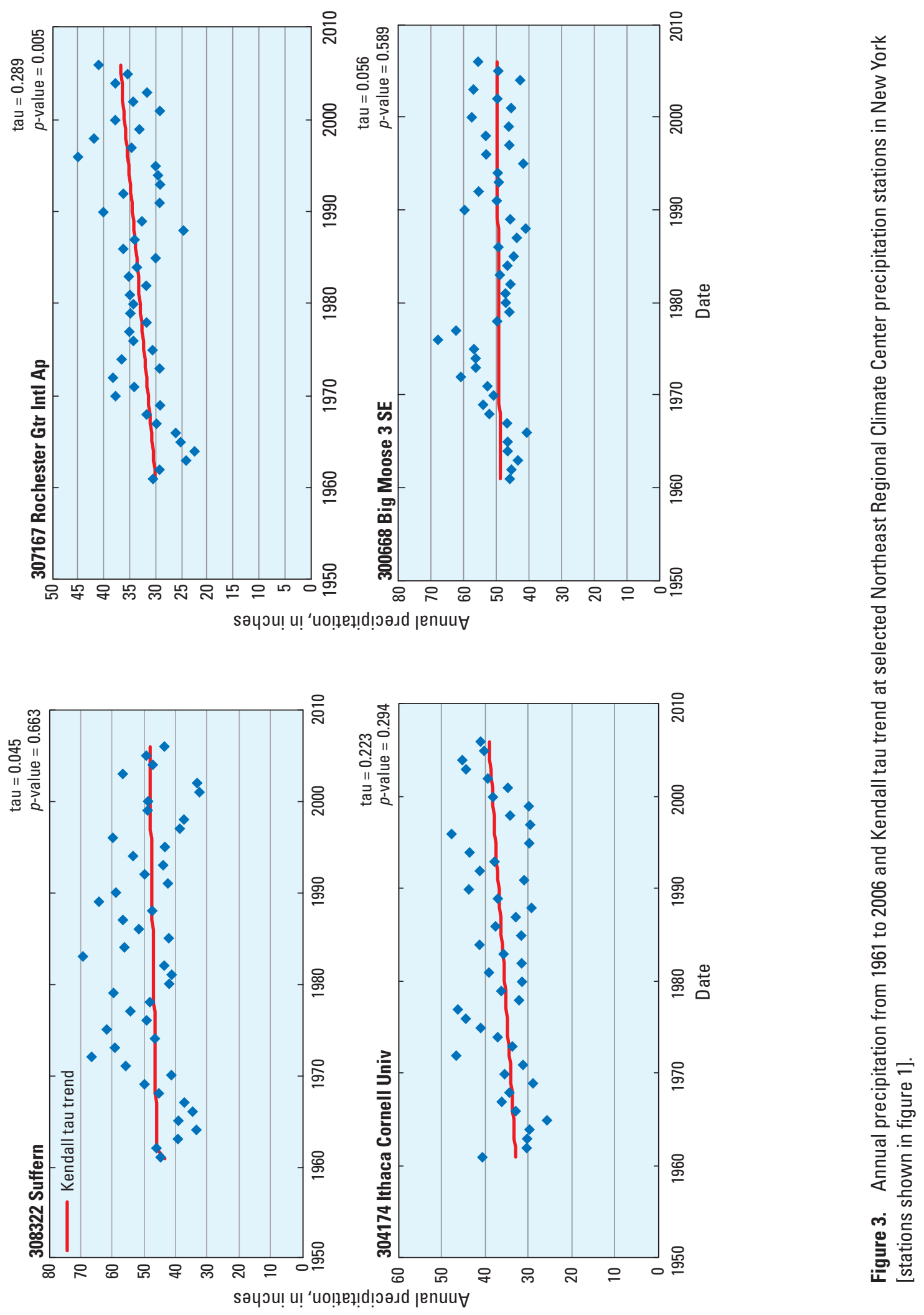

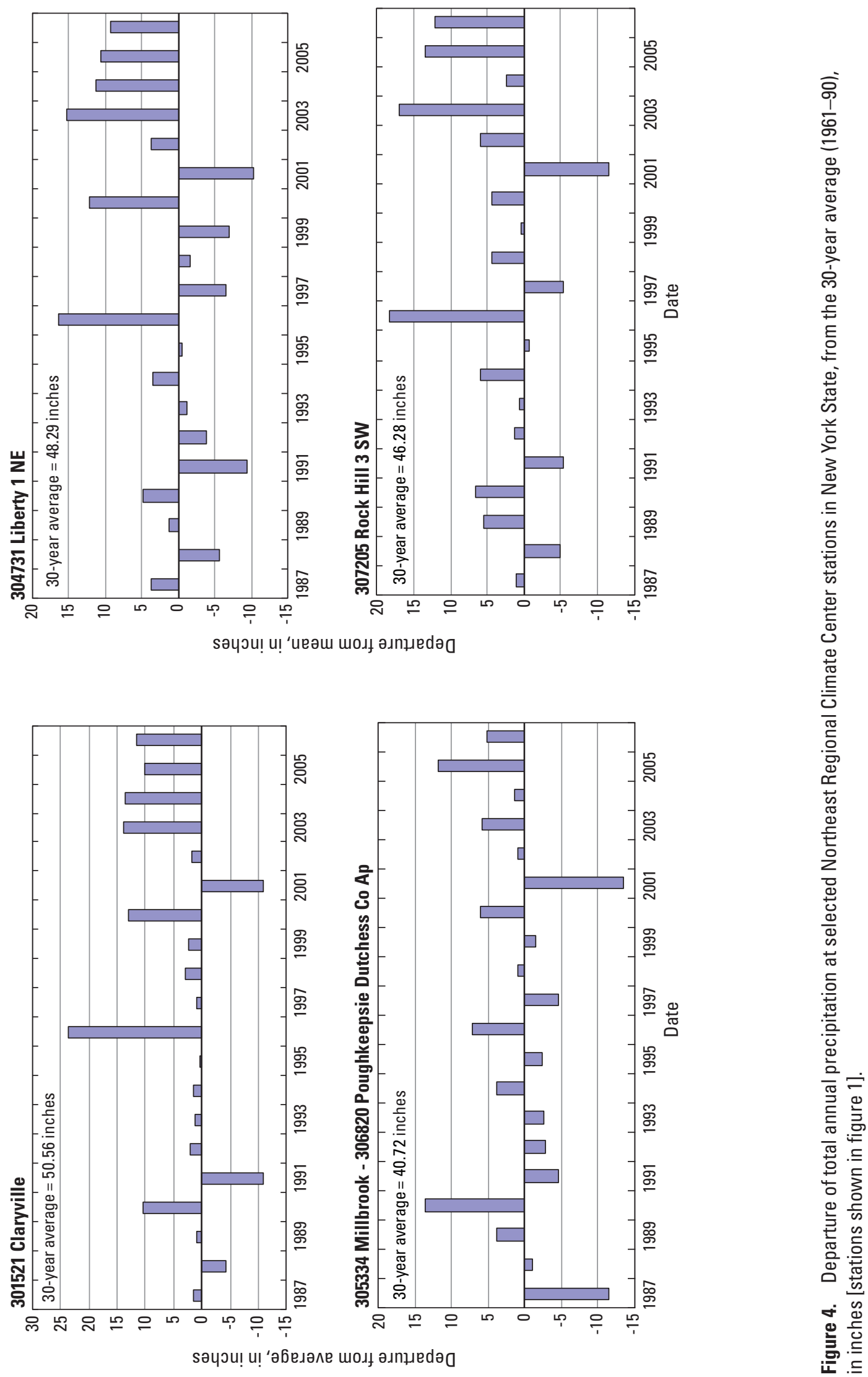

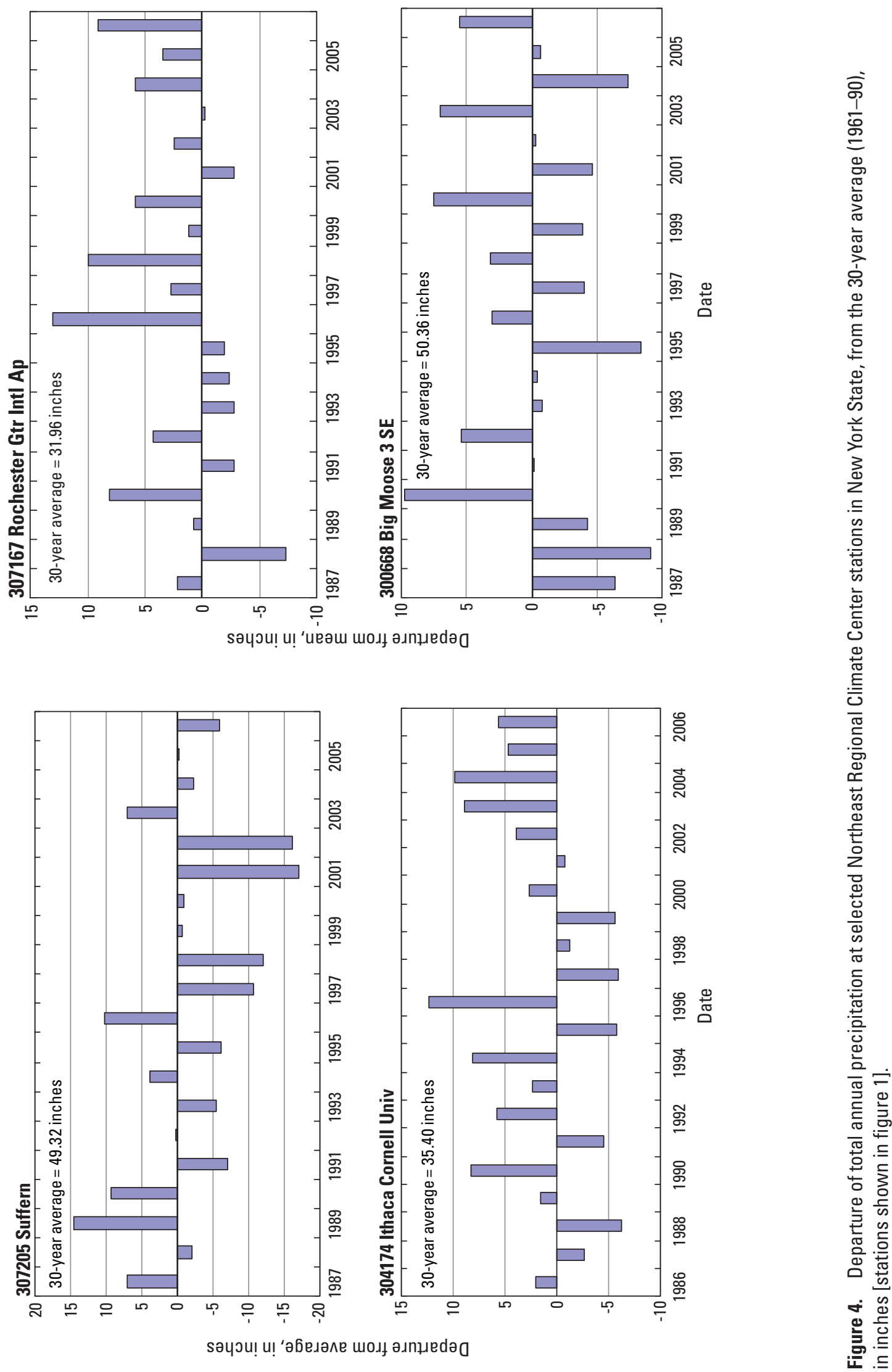

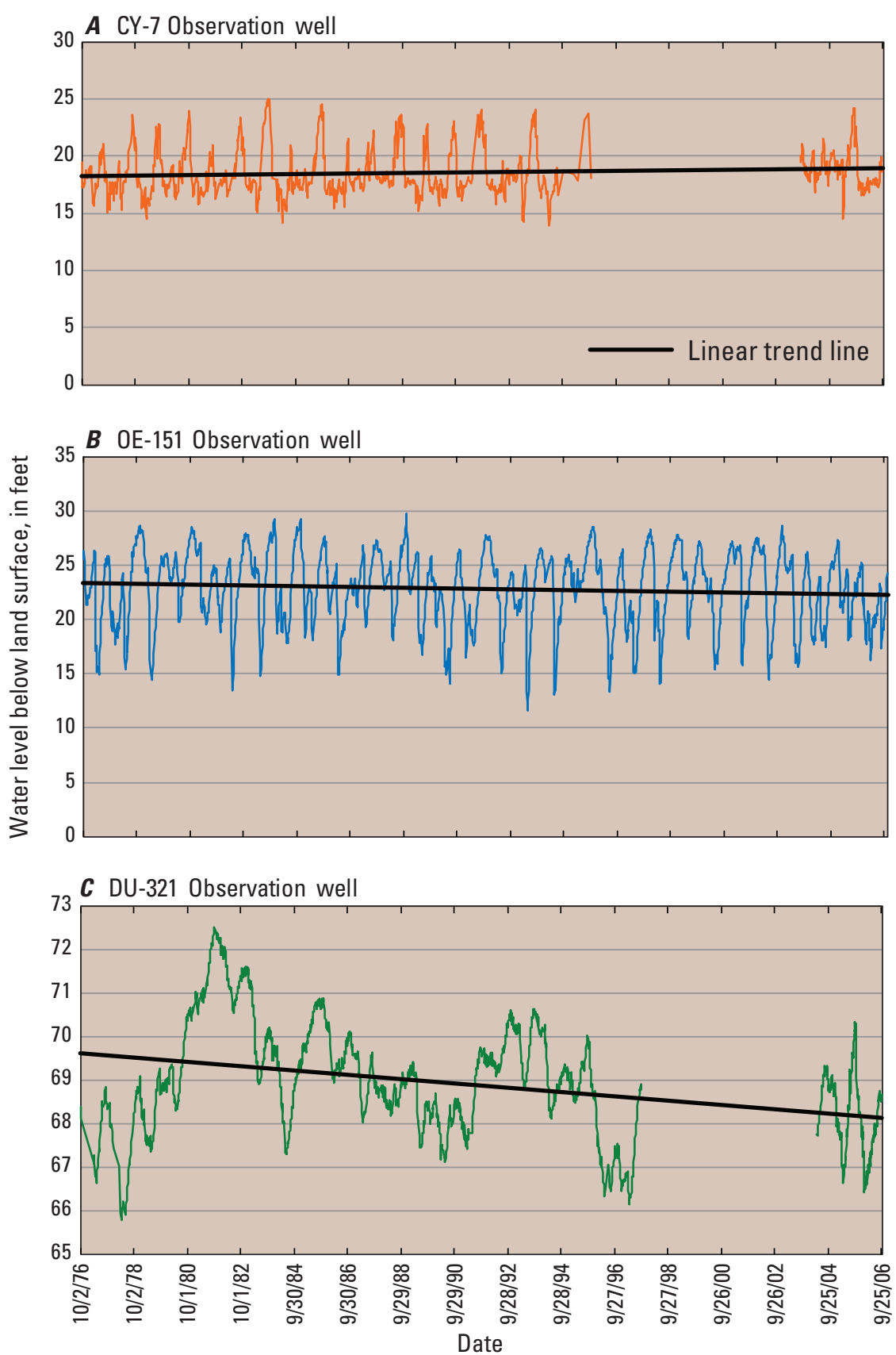

Figure 5. Thirty-year average (1976-2006) hydrographs of weekly water levels at selected U.S. Geological Survey (USGS) groundwater observation wells in New York State. (Well locations are shown in figure 1). 
Trends $\quad 19$

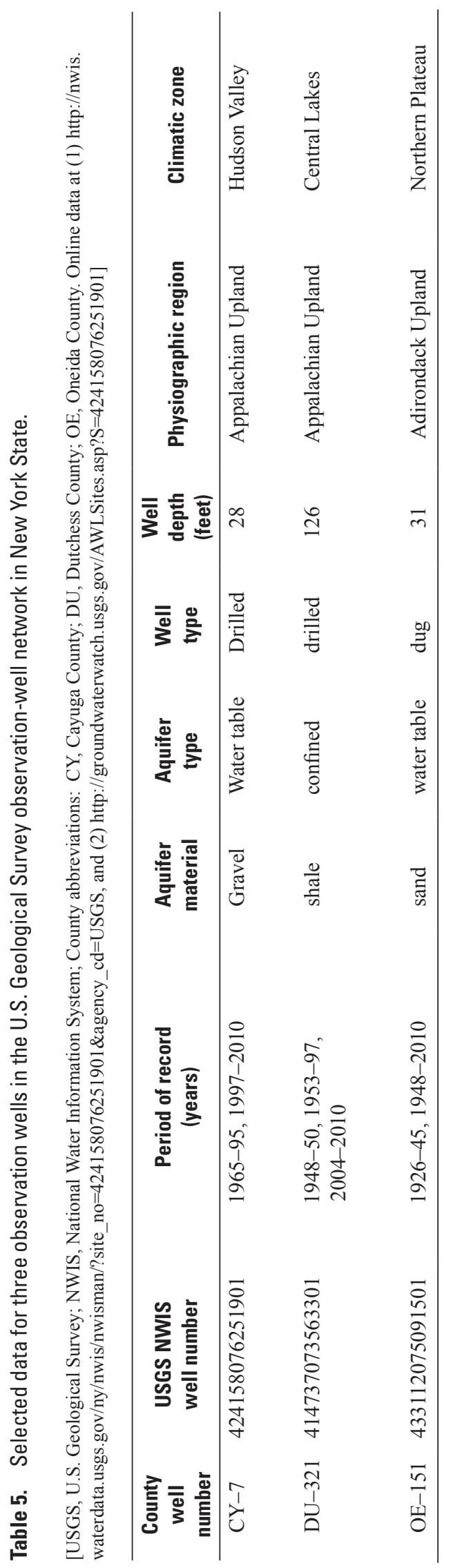


These trends are minor and do not necessarily reflect an impact on low-flow trends at the nearby USGS streamgage. This lack of relation is evident when a comparison is made between the Independence River at Donnattsburg streamgage and well OE-151. The 7Q10 and 7Q2 flows for the streamgage at Independence River at Donnattsburg have increased about 19 and 35 percent, respectively, when computed by using data from 1976 through 2006 and compared to statistics computed by using data from Bulletin 74 (Eissler, 1979). Conversely, the long-term groundwater storage at OE-151 has remained relatively constant and actually shows a minor decreasing trend.

The data from the bedrock well DU-321 shows a fairly constant decrease in groundwater storage during the period 1976-2006. The 7Q10 and 7Q2 flows from the nearby Wappinger Creek streamgage near Wappingers Falls shows an increase of about 3 and 21 percent, respectively, during the period 1976-2006 when compared with data published in Bulletin 74 (Eissler, 1979). The 7Q10 for the Wappinger Creek streamgage shows about a 2 percent increase and about a 7 percent increase in the 7Q2 when data for the entire period of record are used to compute updated statistics. Changes in storage of a confined bedrock aquifer are not usually a good indicator of changes in surface-water baseflows because bedrock aquifers in New York State are hydraulically connected to streams in only a few areas of the State.

These groundwater data indicate a need to install or reactivate groundwater wells to monitor aquifer storage in aquifers that contribute to the base flows at long-term USGS streamgages to assess the effects of groundwater level changes on low flows. Simply selecting locations for groundwater wells on the basis of political boundaries and aquifer type may not provide sufficient data to analyze the effects of changes in groundwater storage on surface-water low flows.

\section{Summary}

Low-flow data are used by many Federal, State, and local permitting and regulatory agencies and by watersupply planners to set policy on surface-water withdraws and to manage reservoirs. Low-flow data also are vital for determining the total maximum daily loads (TMDLs) and effluent limits of point and nonpoint sources of contamination on surface water during periods of decreased streamflow. This study analyzed streamflow data at eight selected streamgages in New York State and data on land use, precipitation, and groundwater near these selected sites to investigate the hypothesis that low-flow conditions and the natural characteristics that strongly influence low flows have changed throughout the State from 1976 through 2006, the period subsequent to that analyzed in Bulletin 74 .

Although the study is limited and cannot be used to determine statewide changes in the low-flow conditions of New York streams, the study does identify an important pattern when data from 1976 through 2006 are used to compute low-flow frequencies and are compared with the low-flow frequencies computed by using data prior to 1976, which were published in Bulletin 74.

The general pattern is that the 7-day 10 year low-flow frequencies showed an increase of about 3 to 19 percent at rural streamgages with unregulated streamflows when computed by using data from 1976 through 2006. The 7-day, 2-year low-flow frequency increased from about 14 to 35 percent at the rural streamgages with unregulated streamflows when the same time period were analyzed.

Streamgages affected by urbanization and regulation for water supply showed the most significant change in the 7-day 2 - and 10-year low-flow frequencies. The 7-day 10-year lowflow frequency increased about 65 percent at the Hackensack River at West Nyack when the data since 1976 were used and about 38 percent when the entire period of record since regulation (46 years) was used. The 7Q10 frequency magnitude for Neversink River at Godeffroy streamgage showed a 120-percent increase when computed by using data from 1976 through 2006 and compared with data published in Bulletin 74. The 7Q10 for Neversink streamgage also showed an increase of about 92 percent when data for the entire period of record since regulation began (1954-2006) were used to compute the low-flow frequency and compared with Bulletin 74. An analysis comparing current (2010) low-flow conditions to preregulation conditions would be necessary to evaluate the effect of regulation on unregulated streamflow and stream ecology at regulated sites.

Seven of the eight precipitation stations near the selected streamgages showed a net positive departure from the 30-year (1976-2006) average precipitation data, and one showed a decreased departure from the 30 -year average. The positive change was most evident during the most recent 10-year (1997-2006) period at many stations. The data for groundwater wells located in sand and gravel aquifers showed minor changes in the groundwater storage from 1976 through 2006 and a lack of relation between the nearby streamgage and the groundwater well.

Groundwater wells used for monitoring water availability in New York State, whether newly installed or reactivated, would need to monitor groundwater storage in aquifers that contribute to the base flows at long-term U.S. Geological Survey streamgages in order to assess the effects of changes in groundwater level on low flows. Selecting locations for groundwater wells simply on the basis of political boundaries and type of aquifer may not provide sufficient data to analyze the effects of changes in groundwater storage on surfacewater flows.

This study has identified a major deficiency in the number of unregulated long-term U.S. Geological Survey streamgages that have remained active since Bulletin 74 was published in 1979 and a complete lack of a network of partialrecord streamgages to determine the low-flow conditions in New York State. Trends in temperature, precipitation, and streamflow have been identified in other studies done in New 
York and the surrounding area. Recent low-flow studies in adjacent states have identified several statistically significant characteristics of basins (such as area of stratified drift, average basin slope, and (or) maximum basin elevation) in addition to drainage area, for improving the accuracy of regression equations to estimate low flows.

This study also has identified the need to use the additional data collected from 1976 through 2006 to compute new low-flow statistics to update those published in two previous reports from 1975 and 1979. These low-flow determinations could be used in conjunction with updated basin characteristics to develop statewide or regional equations for estimating low flows at ungaged streams in New York State.

\section{Selected References}

Barnes, C.R., 1986, Method for estimating low-flow statistics for ungaged streams in the Lower Hudson River basin, New York: U.S. Geological Survey Water-Resources Investigations Report 85-4070, $22 \mathrm{p}$.

Burns, D.A., Klaus, J., and McHale, M.R., 2007, Recent climate trends and implications for water resources in the Catskill Mountain region: Journal of Hydrology, v. 336, p. $155-170$.

Eissler, B.B., 1979, Low-flow frequency analysis of streams in New York: New York State Department of Environmental Conservation Bulletin 74, 176 p.

Flynn, R.H., 2003, Development of regression equations to estimate flow durations and low flow frequency statistics in New Hampshire streams: U.S. Geological Survey WaterResources Investigations Report 02-4298, 30 p.

Helsel, D.R., and Hirsch, R.M., 1992, Statistical methods in water resources: New York, Elsevier, 522 p.

Johnson, M.K., Woodbury, P.B., Pell, A.N., and Lehman, J., 2007, Land-use change and stream water fluxes-Decadal dynamics in watershed nitrate exports: Ecosystems, v. 10, p. 1182-1196.

Ku, H.F.H., Randall, A.D., and MacNish, R.D., 1975, Streamflow in the New York part of the Susquehanna River basin: New York State Department of Environmental Conservation Bulletin 71, $130 \mathrm{p}$.

Lumia, R., 1998, Flood of January 19-20, 1996 in New York State: U.S. Geological Survey Water-Resources Investigations Report 97-4252, 61 p.

New York City Department of Environmental Protection, 2007, History of drought and water consumption: City of New York, N.Y., accessed December 3, 2009, at http://www. nyc.gov/html/dep/html/drinking_water/droughthist.shtml.
Northeast Regional Climate Center, 2008, Climate Information for Management and Operational Decisions (CLIMOD): Ithaca, N.Y., at http://climod.nrcc.cornell.edu/.

Randall, A.D., 2010, Low flow of streams in the Susquehanna River basin of New York: U.S. Geological Survey Scientific Investigations Report 2010-5063, 57 p.

Reynolds, R.J., 2000, Evaluation of the Federal-State cooperative observation well network in upstate New York, 1995-97: U.S. Geological Survey Open-File Report 99-468, $36 \mathrm{p}$.

Ries, K.G., III, 1994, Development and application of generalized-least-squares regression models to estimate low-flow duration in Massachusetts: U.S. Geological Survey Water-Resources Investigations Report 94-4155, $25 \mathrm{p}$.

Riggs, H.C., 1968, Frequency curves: U.S. Geological Survey Techniques of Water-Resources Investigations, book 4, chap. B1, 18 p.

Riggs, H.C., 1972, Low-flow investigations: U.S. Geological Survey Techniques of Water-Resources Investigations, book 4, chap. A2, 15 p.

U.S. Geological Survey, 1979a, Land use and land cover, 1970-76, Hartford, Connecticut; New York; New Jersey; Massachusetts: U.S. Geological Survey Land-Use Map Series, Map L-79, scale 1:250,000.

U.S. Geological Survey, 1979b, Land use and land cover, 1974, Scranton, Pennsylvania; New York; New Jersey: U.S. Geological Survey Land-Use Map Series, Map L-35, scale 1:250,000.

U.S. Geological Survey, 1980, Water resources data for New York: U.S. Geological Survey Water-Data Report NY-79-1, 538 p.

U.S. Geological Survey, 1984a, Land use series, Binghamton [quadrangle], New York: U.S. Geological Survey OpenFile Report 84-532, 5 sheets.

U.S. Geological Survey, 1984b, Land use series, Rochester [quadrangle], New York, U.S.; Ontario, Canada: U.S. Geological Survey Open-File Report 84-30, 1 sheet.

U.S. Geological Survey, 1984c, Land use series, Utica [quadrangle], New York: U.S. Geological Survey OpenFile Report 84-533, 5 sheets.

U.S. Geological Survey, 1985, Land use series, Elmira [quadrangle], New York; Pennsylvania: U.S. Geological Survey Open-File Report 85-318, 5 sheets.

U.S. Geological Survey, 2003, Digital map file of the 2001 National Land Cover Database for New York state, edition 1.0, 30-meter Landsat thematic mapper data: Earth Resource Observation Systems (EROS) Data Center, at http://www.mrlc.gov/nlcd.php 
This page has been left blank intentionally. 
Prepared by the Pembroke Publishing Service Center.

For additional information write to:

New York Water Science Center

U.S. Geological Survey

425 Jordan Road

Troy, NY 12180

Information requests:

(518) 285-5602

or visit our Web site at: http://ny.water.usgs.gov 


\section{㞭}

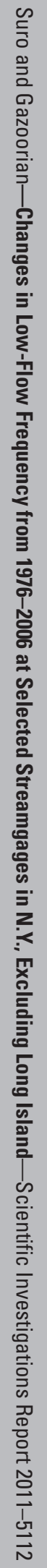

